\title{
A study to assess the effect of planned health teaching programme regarding knowledge and practice on household methods of water purification among the mothers of under five children residing at Sangliwadi, Sangli
}

\author{
Sunil M Kulkarni ${ }^{1 *}$, Manisha S Kulkarni \\ ${ }^{1}$ Associate Professor, ${ }^{2}$ Clinical Instructor, BVDU, CON, Sangli, Maharashtra, India
}

Corresponding Author: Sunil M Kulkarni

Email: sunilmalharkulkarni@gmail.com

\begin{abstract}
Introduction: A Quasi Experimental study was done to assess the effect of planned teaching programme regarding knowledge and practice of household methods of water purification among the mothers of under five children residing at Sangliwadi, Sangli. The objectives of study was to find out the effectiveness of planned teaching programme regarding knowledge and practice on household methods on water purification among the mothers of under five children.

Research Methodology: The research design used was Quasi experimental purposive sampling was used; Sample was selected by interview in the community area of the Sangliwadi. Sample of this study constitute of 30 mothers of under five children residing at Sangliwadi, Sangli. The structured interview schedule and observation checklist was prepared for assessing the knowledge and practice on household methods of water purification among the mothers of under five children.To tool consist of three sections:-Section I: - it included 6 demographic variables, Section II: - Structured interview schedule for assessment of knowledge regarding household methods of water purification and Section III: - includes observation checklist for assessment of practice regarding household methods of water purification. The content validity was determined by 7 experts. The reliability of tool was done by test, re-test method was found to be 0.41 . The data collected from $14^{\text {th }}$ Feb 2011 to $18^{\text {th }}$ Feb 2011.

Study Results: Major findings of study were:- Most of the samples of $63.4 \%$ are educated till $10^{\text {th }}$ standard. The planned teaching program was effective. There was an association between the education and awareness regarding household methods of water purification.
\end{abstract}

Conclusion: The teaching on household water purification method health to prevents many water borne diseases to under five children.

Keywords: Knowledge, Practices, Household water purification methods and Mothers of under fives.

Water pollution is a growing hazard in many developing countries due to human activity. Water is an essential factor in the economic, social and cultural development of community. It can eliminate diseases, and improve quality of life

Quasi Experimental study to assess the effect of planned teaching programme regarding knowledge and practice of household methods of water purification among the mothers of under five children residing at Sangliwadi, Sangli.

\section{The objectives of study where}

1. To assess the existing knowledge on household methods on water purification among the mothers of under five children.

2. To find out the effectiveness of planned teaching programme regarding knowledge and practice on household methods on water purification among the mothers of under five children.

3. To find out the association between the knowledge and practice of household methods on water purification and socio-demographic variables as (age, education and occupation) among the mothers of under five children residing at Sangliwadi, Sangli.

As per Imogene Kings Goal Attainment Theory conceptual frame was made which includes knowledge and practice among the mothers of under five children regarding household methods on water purification such as boiling, chemicals disinfection and filters. The research design used included 3 interaction systems

The personal, interpersonal and social system and elements of theory of goal attainment like interaction, perception, communication and transaction. The research design used was Quasi experimental with purposive sampling was used; Sample was selected by interview in the community area of the Sangliwadi. Sample of this study constitute of 30 mothers of under five children residing at Sangliwadi, Sangli. The structured interview schedule and observation checklist was prepared for assessing the knowledge 
and practice on household methods of water purification among the mothers of under five children.

\section{To tool consist of three sections}

Section I: it included 6 demographic variables (age, education, occupation).

Section II: it consists of 12 items of structured interview schedule for assessment of knowledge regarding household methods of water purification.

Section III: it consists of 10 items which includes observation checklist for assessment of practice regarding household methods of water purification.

The content validity was determined by 7 experts. The reliability of tool was done by test, re-test method was found to be 0.41 .
The data collected from $14^{\text {th }}$ Feb 2011 to $18^{\text {th }}$ Feb 2011.

\section{Major findings of study were}

$50 \%$ of mothers of under five children's were from age group of 25 Years one month to 30 years, $30 \%$ mothers were from age group of 20 years one month to 25 years and $16.7 \%$ mothers were from age group of 30 years one month to 35 years.

Most of the samples of $63.4 \%$ are educated till $10^{\text {th }}$ standard, and $16.6 \%$ are educated till $12^{\text {th }}$ standard, the graduates were of $20 \%$. There is an association between the education and awareness regarding household methods of water purification.

Table 1: Distribution of knowledge score based on percentage and frequency

\begin{tabular}{|c|l|c|c|c|c|}
\hline S. No & Sample characteristics & \multicolumn{2}{|c|}{ Pre test } & \multicolumn{2}{c|}{ Post test } \\
\cline { 3 - 5 } & & freq & \% & freq & \% \\
\hline 1. & Meaning of safe drinking water & 19 & 63.03 & 30 & 100 \\
\hline 2. & Method of household water purification & 29 & 96.06 & 30 & 100 \\
\hline 3. & Elements taken of by cloth sieve & 22 & 73.03 & 30 & 100 \\
\hline 4. & boiling duration of water & 20 & 66.06 & 28 & 93.03 \\
\hline 5. & Which are not the benefits of boiling water & 07 & 23.03 & 09 & 30 \\
\hline 6. & Advantages of alum & 19 & 63.03 & 28 & 93.03 \\
\hline 7. & Disadvantages of alum & 19 & 63.03 & 28 & 93.03 \\
\hline 8. & A chlorine tab 0.5 gm is dissolved in 20liters of water & 08 & 26.06 & 21 & 70 \\
\hline 9. & Colour of bleaching powder & 18 & 60 & 29 & 96.03 \\
\hline 10. & Bleaching powder is stored in cool, dry, dark place & 09 & 30 & 18 & 60 \\
\hline 11. & Elements taken off by ceramic filter & 27 & 90 & 20 & 66.06 \\
\hline 12. & Interval to clean the candle & 05 & 16.06 & 24 & 80 \\
\hline
\end{tabular}

Above table values shows that there is maximum knowledge regarding boiling \& cloth sieve methods for water purification as in pretest it was $29[96.6 \%]$ \& $22[73 \%$ ] \&later it was $100 \%$ in both method. The knowledge of Alum had doubled as from 19[63.3\%] to28 [93.3\%].The mothers had limited knowledge regarding chlorination as $-8[26.6 \%] \&$ knowledge was gained to $70 \%$. There was confusion regarding elements taken off by ceramic filter so the score were $-7[-23.4 \%]$.

Table 2: Distribution of practice score based on percentage and frequency.

\begin{tabular}{|c|l|c|c|c|c|}
\hline $\begin{array}{c}\text { S. } \\
\text { No }\end{array}$ & \multicolumn{1}{|c|}{ Sample characteristic } & yes & & No & \\
\cline { 3 - 5 } & & Freq & $\mathbf{\%}$ & freq & \% \\
\hline 1. & Strains water before boiling & 16 & 53.03 & 14 & 46.06 \\
\hline 2. & Boils water for 10-20 min & 13 & 43.03 & 17 & 56.06 \\
\hline 3. & Strains water after boiling & 19 & 63.03 & 11 & 36.06 \\
\hline 4. & Covers the water after boiling & 27 & 90 & 03 & 10 \\
\hline 5. & Does taste changes & 24 & 80 & 06 & 20 \\
\hline 6. & Add chlorine tab in 1 bucket & - & - & 30 & 100 \\
\hline 7. & Keeps water for 30 min after chlorination & - & - & 30 & 100 \\
\hline 8. & Does taste change & - & - & 30 & 100 \\
\hline 9. & Wash hands while using alum & 03 & 10 & 27 & 90 \\
\hline 10. & Keep alum in water for more than 5 min & 10 & 33.03 & 20 & 66.06 \\
\hline
\end{tabular}


The table depicts that the 16(53.3\%)of the mothers practice boiling of water but the faulty timing is used by $17(56.6 \%)$ of mothers, about $27(90 \%)$ mothers cover water after boiling there is no practice of chlorine tablet the mothers used alum for purification but practices are not satisfactory as 10(3303\%) mothers practice use of alum.There is an association between the education and awareness regarding household methods of water purification.

Table 3: Paired Samples ' $t$ 'Test

\begin{tabular}{|c|c|c|c|c|c|c|c|c|c|}
\hline & & \multicolumn{5}{|c|}{ Paired Differences } & \multirow[t]{3}{*}{$\mathrm{t}$} & \multirow[t]{3}{*}{$\mathrm{df}$} & \multirow[t]{3}{*}{ Conclusion } \\
\hline & & \multirow[t]{2}{*}{ Mean } & \multirow[t]{2}{*}{$\begin{array}{c}\text { Std. } \\
\text { Deviation }\end{array}$} & \multirow[t]{2}{*}{$\begin{array}{l}\text { Std. Error } \\
\text { Mean }\end{array}$} & \multicolumn{2}{|c|}{$\begin{array}{l}95 \% \text { Confidence } \\
\text { Interval of the } \\
\text { Difference }\end{array}$} & & & \\
\hline & & & & & Lower & Upper & & & \\
\hline $\begin{array}{c}\text { Pair } \\
1\end{array}$ & $\begin{array}{c}\text { Post_and } \\
\text { Pre_test score }\end{array}$ & 3.100 & 1.729 & .316 & 2.454 & 3.746 & 9.820 & 29 & Significant \\
\hline
\end{tabular}

Planned teaching program was effective as 't' calculated value 9.82 was much more than ' $t$ ' table value.

\section{Discussion}

This study results were supported by following research studies. (Reshma, Mamatha S. Pai \& Manjula.2016). A descriptive study to assess the knowledge and practice regarding water, sanitation and hygiene among women in selected villages of Udupi district. The study findings revealed that out of 300 subjects, $40 \%$ had good knowledge, $42 \%$ had average knowledge and $18 \%$ had poor knowledge on water, sanitation and hygiene. Findings of the study revealed that majority $(75 \%)$ of the subjects followed unsafe practices on water, sanitation and hygiene. Study found that there is significant association between 22 knowledge and age $(\chi=4.60 ; p<0.05)$, education $(?=1.34 ; 2 \mathrm{p}<0.05)$, occupation $(?=1.09$; $\mathrm{p}<0.05)$, family income per 2 month $(\chi=0.9 ; \mathrm{p}<0.05)$, information on water, sanitation 2 and hygiene $(?=$ $1.38, \mathrm{p}<0.05)$. The study inferred that as knowledge increases practiceImproves

(Nitinkumar V S Jatinkumar 2019) a. study on knowledge, attitude and practice about purification of household water among 210 individuals of urban area of Patan district. However, married (18.3\%) and literate $(22.6 \%)$ respondents had better knowledge as compared to unmarried $(6.7 \%)$ and illiterate $(8.1 \%)$ respondents respectively ( $\mathrm{p}<0.05$ in both groups). Most of the respondents $(184,87.6 \%)$ showed positive attitude for doing purification of water. Author concluded that well designed health awareness programs should be effectively implemented with active participation of health workers (Rima Kumari Sah1, Prem Kumar Sah2 et.al.2017). Assessment of the knowledge, attitude and practice regarding water, sanitation and hygiene among mothers of under-five children in rural households of Saptari district, Nepal. appropriate knowledge (74.8\%) and poor knowledge (25.71\%) on water, Sanitation and hygiene. $57.14 \%$ participants had positive attitude on water, sanitation and hygiene while $(42.85 \%)$ had negative attitude. Regarding practice, (60\%) participants did good practice and (40\%) did poor practice. A statistically significant difference in the level of knowledge, attitude and practice of participants was seen according to their educational level at $p<0.05$. Present study showed that there is a need to spread information on the importance of proper practice on water, sanitation and hygiene

\section{Conclusion}

The study results showed that teaching of water purification methods at home was effective, economical and practical approach to prevent so many water borne diseases.

\section{Source of funding}

None.

\section{Conflict of interest}

None.

\section{References}

1. Park. K. Park's textbook of Preventive and Social Medicine. $20^{\text {th }}$ edition, Jabalpur. M/S Banarasidas Bhanot Publication. page. No.625-627.

2. B.T Basvantappa, Text Book of Community Health Nursing. $2^{\text {nd }}$ edition. New Delhi.

3. Japee Brothers Publishers, Page no. 299-300.

4. en.wikipedia.org/wiki/Portable_water_purification

5. www.ciese.org/curriculum/purification/reference.html

6. www.uptodate.com/contents/water-purification-systems-in 
7. www.juliantrubin.com/fairprojects/.../waterpurification.htm 1

8. Reshma, Mamtha S, Pal \& Manjula. A descriptive study to assess the knowledge and practice regarding water, sanitation and hygiene among women in selected villages of Udupi district. NUJHS 2016;6(1):21-28

9. Nitinkumar V S Jatinkumar. A study on knowledge, attitude and practice about purification of household water among 210 individuals of urban area of Patan District. NJCM 2019;10 (7) :420-431.
10. Assessment of the knowledge, attitude and practice regarding water, sanitation and hygiene among mothers of under-five children in rural households of Saptari district, Nepal. AJPHR 2017;5(5);163-9.

How to cite: Kulkarni SM, Kulkarni MS. A study to assess the effect of planned health teaching programme regarding knowledge and practice on household methods of water purification among the mothers of under five children residing at Sangliwadi, Sangli. IP J Paediatr Nurs Sci 2020;3(1):24-7 